\title{
Social inequalities in lawsuits for drugs
}

\author{
Mércia Pandolfo Provin ${ }^{1, *}$, Silvana Nair Leite², Rita Goreti Amaral ${ }^{3}$
}

${ }^{\text {}}$ School of Pharmacy, Federal University of Goiás, Goiânia, GO, Brazil, ${ }^{2}$ Department of Pharmacy, Federal University of
Santa Catarina, Florianopolis, SC, Brazil, ${ }^{3}$ School of Pharmacy, Federal University of Goiás, Goiânia, GO, Brazil

\begin{abstract}
The aim of this study was to characterize the lawsuits requesting drugs considering the economic profile of their petitioners. All lawsuits (1378) accepted against Goiânia, GO from 2003 to 2007 were analyzed. Petitioners' demographic characteristics, reported diseases, requested drugs, origin of healthcare service, and lawsuit agent were described. Complainants' addresses were georeferenced and distributed into 4 regional groups classified in accordance with the population's average income. Dwellers of wealthier regions filed court actions requesting drugs more frequently, with an average rate of 1.7 lawsuits/1000 inhabitants versus $0.55 / 1000$ in the poorer region. Lawsuit costs were 4-fold higher in wealthier regions compared with the poorest region. Chronic diseases were involved in most lawsuits, where acute and low complexity diseases predominated among complainants living in poorer regions. Thus, social differences were reflected in the granting of health rights.
\end{abstract}

Uniterms: Health rights. Drugs/access. Health inequalities. Health care.

Este estudo teve como objetivo caracterizar as ações judiciais que solicitaram medicamentos considerando o perfil econômico de seus impetrantes. Foram analisadas as ações judiciais deferidas contra Goiânia, GO, no período de 2003 a 2007, totalizando 1378. Descreveram-se as características demográficas dos impetrantes, as doenças relatadas, os medicamentos solicitados, a origem do serviço de assistência e o condutor da ação. Os endereços dos impetrantes foram geoprocessados e distribuídos em quatro grupos classificados de acordo com a renda média da população. Foi observado que os moradores de regiões ricas impetraram mais ações, 1,7 ações/1000 habitantes em comparação com 0,55/1000 na região mais pobre. Os custos das ações judiciais também foram maiores nessas regiões, sendo quatro vezes mais caros dos que as das regiões mais pobres. As doenças crônicas estavam presentes na maioria das ações; entre os impetrantes que moravam em regiões mais pobres, as doenças agudas e de menor complexidade tiveram mais destaque. Assim, as diferenças sociais são refletidas na concessão do direito à saúde.

Unitermos: Direito à saúde. Medicamentos/acesso público. Saúde/desigualdades de acesso. Assistência a saúde.

\section{INTRODUCTION}

Access to health care services in Brazil is free, universal and grants full assistance to its users, include pharmaceutical. The Unified Health System (UHS or Sistema Único de Saúde - SUS in Portuguese) is organized into a hierarchical and regionalized network which provides assistance through its own health units or through affiliated private institutions (Brazil, 1988, 1990).

\footnotetext{
*Correspondence: M. P. Provin. Faculdade de Farmácia, Universidade Federal de Goiás. Avenida Universitária, Campus I, Setor Universitário, 74605-220 Goiânia-GO, Brasil. E-mail: merciap@gmail.com
}

However, in the last few years an increasing number of citizens have brought court actions to grant access to drugs prescribed for their treatments and this litigation has become a management and financial problem for the national and local health systems (Messeder, Osorio-deCastro, Luiza, 2005). This phenomenon has been coined health "judicialization".

Some authors hold that lawsuits have become instruments of inequality in access and irrationality in use of public resources when they rule the provision of drugs which are not standard under the public health system or when they contravene SUS and Pharmaceutical Assistance regulations (Vieira, Zucchi, 2007; Silva, Terrazas, 2009). On the other hand, others recognize legitimacy in control 
of public policy by the Judicial Powers in as far as this broadens the democratic debate to include the adoption of counter-majoritarian positions (Appio, 2007; Freire, 2003). Positions in the conflicting literature reveal a lack of consensus on the issue.

Lawsuits requested a myriad of types of drugs, most of which were included in the official lists of drugs for public distribution, others presented standard therapeutic alternatives, while a small proportion represented assistance gaps or new technologies that have not yet been incorporated by the SUS (Messeder, Osorio-de-Castro, Luiza, 2005; Vieira, Zucchi, 2007; Pereira et al., 2003; Romero, 2008; Bonfim, 2008; Leite et al., 2009; Chieff, Barata, 2009; Borges, Ugá, 2010). Whether opposing the policies of public health or otherwise, the judicial demand for drugs may reflect the conditions of access to the health service by citizens.

The pattern of access to health services is strongly influenced by people's social conditions and the availability of access to complementary private health (Travassos, Oliveira, Viacava, 2006; Silva et al.., 2000). Delay in provision of services, excess referral of patients to other services, shortage of doctors and deficiencies in the facilities are some aspects reported by users as shortcomings regarding the use of the public health system (Schwartz et al.., 2010).

Therefore, geographical and social differences are important as determinants of health and health services access. Analysis, for example, of the utilization rate of health services among different regions, cities and also on an intra-city basis, reveals the geographical dimension of the differences in local financing capability, individual access and the size and complexity of service networks available (Travassos, 1997).

In the case of drugs, access may be free and citizens have to join SUS and accept its whole set of technicalorganizational regulations, which include respecting its actions hierarchy, regionalization and standard procedures. Those citizens not accepting these conditions may opt for the supplementary private system, whose expenses are covered by the users through insurances or health plans. In these cases, the assistance offered is stipulated under the contractual terms and conditions.

The judicial route, as previously discussed, has become a means of gaining access to drugs, but it is unclear whether litigation is an equalitarian solution or the extent to which social and geographical differences influence its characteristics.

Therefore, the objective of this study was to characterize the demand for drugs through the judicial route in regions with different incomes.

\section{METHODOLOGY}

A cross-sectional, descriptive study was carried out at the School of Pharmacy - Federal University of Goiás, previously approved by the Ethics Committee of the institution. The study involved the analysis of court actions demanding drugs that were accepted and granted at the city of Goiânia-GO-Brazil.

The study comprised all court actions demanding drugs brought against the city of Goiânia-GO that were accepted and received by the Unified Health System manager from January 2005 to December 2007.

Lawsuits which requested at least one drug and resulted in legal proceedings in the Municipal Nonessential Medication Pharmacy, the unit responsible for purchasing, storage and dispensing drugs, were included in the study. Lawsuits that did not request drugs or lacking full address for geoprocessing were excluded.

Data was collected using a standard form gathering information on subject of lawsuits, the petitioners and drugs involved, in addition to the health system that had made out the prescription.

The variables of interest were: (a) court actions: number of lawsuits, year granted, agent guiding action, type of court action; (b) petitioner: petitioner number, basis and associated diseases reported, gender, age, place of residence, income; (c) origin of prescriptions; and (d) drugs: cost, availability of the pharmacological therapy and alternative therapeutics.

Due to the lack of information concerning the cost of each drug provided by the Municipal Health Secretariat/Goiânia, it was necessary to assign prices to them in accordance with the following strategy: for each pharmaceutical specialty requested, the reference drug was adopted according to definitions in Law No. 9787/99 (Brazil, 1999), the value assigned to each provided item was drawn from the consumer price list consulted on the Brasíndice Pharmaceutical Guide, editions from 2003 to 2007 , considering a $17 \%$ taxation rate plus a $30 \%$ discount on the average profit of retail sales. Regarding drugs with floating price and/or imported, the prevailing market prices were used, and the deflation index applied for the period in question, to arrive at the hypothetical prices in the year of delivery.

Pharmacological therapy availability was analyzed by comparing the requested drugs against the Brazilian Common Denomination (BCD), and checking for their accessibility in the drugs lists of the Municipal List of Essential Drugs (LEM, Relação Municipal de Medicamentos Essenciais - REMUME in Portuguese) and the High Cost and Exceptional Circumstance Dispensing 
Drugs Program, now called Specialized Component of Pharmaceutical Assistance (SCPA).

For analysis of the therapeutic alternative availability in the public health service, the requested drugs were compared with official lists that make the three components defined in the Pharmaceutical Assistance Policy: basic component, strategic component and exceptional dispensed drugs component. Those drugs not contained in any of the lists were included and classified based on the Anatomical Therapeutic Chemical (ATC) Classification System, proposed by the World Health Organization Collaborating Center (WHO) for drugs methodology, from Oslo, Norway and the International Working Group for Drug Statistics, located in Geneva, Switzerland, which defines the directives in applying this methodology (Word Health Organization, 2010). Drugs having a therapeutic alternative were considered those requested through court actions that belonged to the same therapeutic subgroup ( $3^{\text {rd }}$ level in the ATC classification) as others present in the lists of the public health system.

In order to characterize the drugs demanded through the judicial route in different city regions and to determine the public coverage for pharmacological therapy, the court actions were processed and the related information present in the collection forms was consolidated using Microsoft Office Excel 2007. At this stage, 129 lawsuits were excluded for having incomplete data, giving a total of 1,249 lawsuits analyzed.

Subsequently, the lawsuits from among 63 Territorial Basic Units (TBU) of Goiânia were described and distributed by geoprocessing. These TPUs each correspond to a neighborhood or a set of neighborhoods, delimited by physical barriers, such as transport system, rivers and minor watercourses which split up parts of the urban space that have a significant level of homogeneity. The population data and the average income of the breadwinners (in Reais) of each TBU were gathered from the 2000 census data (Brasil, 2003). The average income was then converted into minimum wages at a reference amount of R\$ 151.00 as defined in Law No. 9971 of 05/18/2000.

After geoprocessing, the court actions were grouped in accordance with the estimated average income of the family breadwinner for the respective TBU, into four groups as follows:

- $\quad$ Region type I: set of court actions filed in regions where the average income is from 0 to 3 (included) minimum wages;

- Region type II: set of court actions filed regions where the average income is higher than 3 to 6 (included) minimum wages;
- $\quad$ Region type III: set of court actions filed in regions where the average income is higher than 6 to 9 (included) minimum wages;

- $\quad$ Region type IV: set of court actions filed in regions where the average income is greater than 9 minimum wages.

The following sources were used: (a) for court action data, the suits filed at the Nonessential Drugs Pharmacy of the Municipal Health Secretariat; (b) for census data, the IBGE (Brasil, 2003); and (c) for drug costs, the Brasíndice Pharmaceutical Guide - 2005 to 2007, was employed.

The financial importance of each drug in the court action costs were analyzed for the two income extremes (Regions I and IV) using the Pareto Analysis, also known as the $\mathrm{ABC}$ curve, which allows them to be listed from most to least important, making it easier to visualize and identify those drugs which need most attention (Rosa, Gomes, 2001). The drugs were thus classified into three groups (A, B and C) according to their relative weight in the court action costs. After calculating the items' relative costs, they were arranged in decreasing order. The groups A, B and C were then defined. Group A, of higher financial importance, corresponded to those drugs that, when added, represented $75 \%$ of costs. Drugs in group $\mathrm{C}$, although corresponding to the largest proportion, only represented a low proportion of costs, at about $10 \%$. Group $\mathrm{B}$ represented the intermediary cases between groups A and C. For the curve calculus, monetary values from 2007 were used as a base.

After characterization and distribution of the demands for drugs though lawsuits in different regions of the city (TBUs), these were categorized into four groups according to the population's median income and examined to determine whether the lawsuit characteristics varied according to income.

Analyzed variables were then compared for the income groups. It should be noted that for these analyses the sample units corresponded to the TBUs, i.e., when there is, for example, an average, this number represents the average of all TBUs that met the characteristics of the group. The Kruskal-Wallis test was applied since the data did not generally follow a normal distribution.

The following definition was used to identify the groups: 0-3 MW, monthly income of 0 to 3 minimum wages; 3-6 MW, average income of 3 to 6 minimum wages; 6-9 MW, average income of 6 to 9 minimum wages; and Over $9 \mathrm{MW}$, income higher than 9 minimum wages.

A level of significance of 0.05 was adopted for the tests. 


\section{RESULTS}

The survey carried out at the Non-Essential Pharmacy of Goiânia found 1,344 petitioning citizens who filed a total of 1,378 lawsuits demanding different drugs from January 2003 to December 2007.

The number of lawsuits filed per year rose from 2003 (96) to 2006 (481), where in 29 cases the date granted was not found. In 2007, the number of new writs fell by $46.7 \%$, totaling 225, but the reasons for this decrease has not yet been investigated (Figure 1). Even though the number of new suits had fallen in 2007, a commensurate decrease in the number of treatments in the same year was not observed. This is due to the cumulative characteristic of court actions.

Most of the lawsuits involved chronic illnesses such as Type 1 Diabetes Mellitus (25.75\%), hypertension $(9.45 \%)$, mood disorders $(6.36 \%)$, Type 2 Diabetes

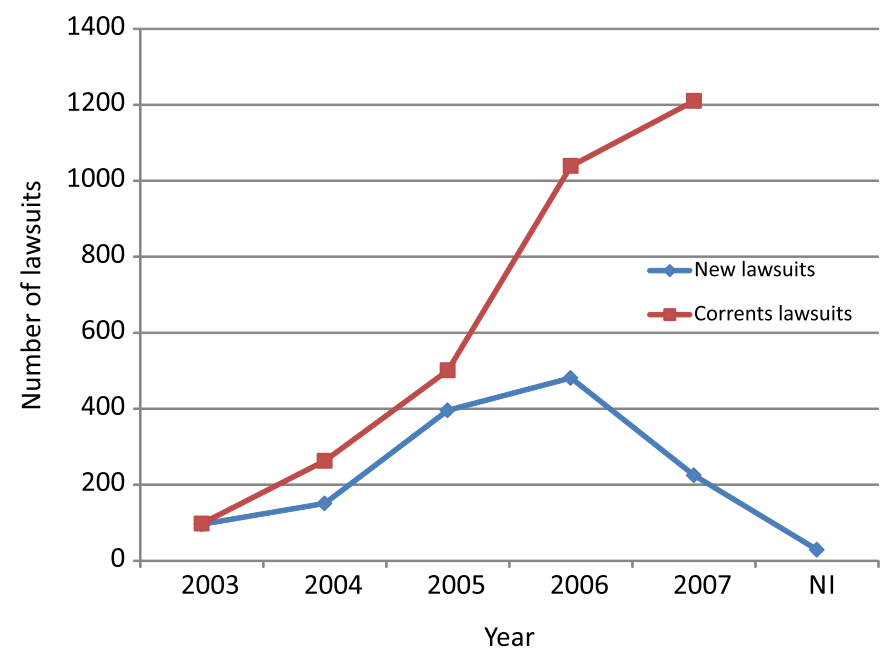

FIGURE 1 - Number of new lawsuits filed against the Municipal Health Secretariat and number of current lawsuits (year not given in 29 lawsuits), 2003-2007, Goiânia - GO.
Mellitus (4.40\%), lactose intolerance and gastroesophageal reflux disease (4.24\%), among others.

Older adults (over 60 years old) and children ( 0 to 10 years old), represented $47.1 \%$ of the total petitioners. The most frequent health problems in court actions among children were gastroesophageal reflux disease and lactose intolerance. The most frequent cause in the 11-15 years age group, which accounted for $22.1 \%$ of the lawsuits, was Type 1 Diabetes.

Insulin was the main request of petitioners who were Type 1 Diabetes Mellitus sufferers, corresponding to R\$ $1,242,009.39(23.24 \%)$ of the overall costs with judicially demanded drugs $(\mathrm{R} \$ 5,344,274.50)$. The insulin analogues represented $90.91 \%$ of insulin units provided and Glargine corresponded to $44.20 \%$ of the requests, Lispro to $25.82 \%$, Aspart to $27.76 \%$ and Detemir to $2.22 \%$.

The vast majority of lawsuits were writs of mandamus ( $94.4 \%$ of cases), mainly brought by State Public Prosecutors while the remainder were in the hands of private law offices.

Most petitioners were women, representing 54.5\%.

The prescriptions which led to lawsuits were made out under the private health system in $56.4 \%$ of cases and $18.1 \%$ from the public system whereas in $25.5 \%$ of cases it was not possible to identify the prescription's origin.

Petitioners requested 482 different drugs of which 93 (19.3\%) were available at REMUNE, 48 (10\%) from the High Cost and Specialized Component of Pharmaceutical Assistance (SCPA) and 8 (1.7\%) existed on both these lists. Thus, $333(69.3 \%)$ of the requested drugs were not present in any official list of drugs for public distribution, however, $139(41.7 \%)$ of this group had at least one therapeutic alternative available (Figure 2).

Of the 1.378 lawsuits included in this analysis, 129 were excluded from the geoprocessing because the address was incomplete.

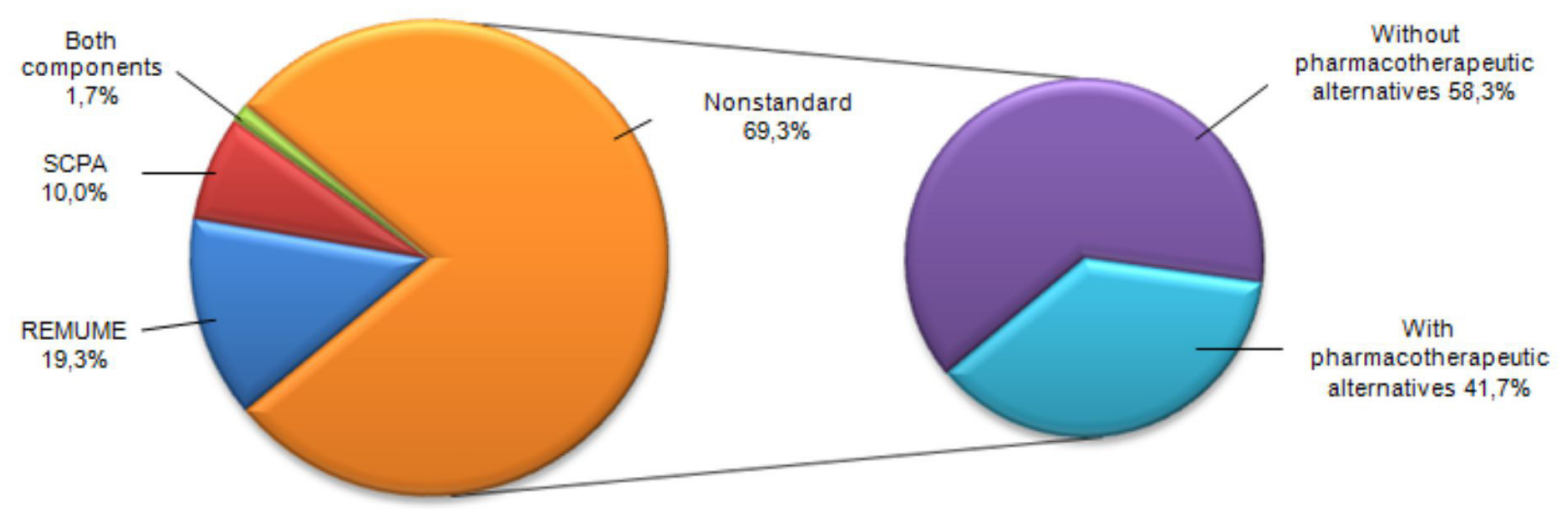

FIGURE 2 - Distribution of requested drugs in official lists for public access and existence of therapeutic alternatives. SCPA: Specialized Component of Pharmaceutical Assistance; REMUME: Municipal List of Essential Drugs. 
The judicial demand characteristics varied among the intra-city regions where breadwinner incomes differed and are depicted in Table I.

The number of lawsuits increased as income rose, whereby regions with the highest income (Type IV Regions) had three times more lawsuits than Type I Regions representing the lowest income.

Lawsuit costs also presented a similar profile. The average cost of suits brought by petitioners living in regions with the highest income (Type IV Regions) was higher than from regions with the lowest income (Type1 Regions), reaching costs four times higher.

There were no significant differences among the regions regarding the frequency at which the nonstandard drugs were requested or proportion of those which represented lack of assistance.

Although the frequency that petitioners requested nonstandard drugs was similar across the regions, it was evident that individuals with higher income requested more nonstandard drugs, proportionally, than those with lower income.

The $\mathrm{ABC}$ curve of drugs demanded in regions with the highest and the lowest incomes (Regions I and IV, respectively) offers some information that helps elucidate the differences between these regions. Group A of ABC curve is depicted in Table II.

Results showed that bacterial infections was the main therapeutic need indicated as the reason for requesting drugs in Type 1 Regions, while in Type IV Regions Type 1 Diabetes Mellitus was the leading reason.

Except for cancer, which represented high costs in both regions, the therapeutic indications in Type I Regions comprised a mix of illnesses of minor complexity and consequently represented lower costs in comparison with those in Type IV Regions.

TABLE I - Characteristics of judicial demands by intra-city region with different incomes

\begin{tabular}{|c|c|c|c|c|c|}
\hline & \multicolumn{5}{|c|}{ Lawsuits grouped by average minimum wage (MW) in respective regions } \\
\hline & Type 1 Regions & Type 2 Regions & Type 3 Regions & Type 4 Regions & Value $p^{*}$ \\
\hline & 0 to 3 MW & 3 to $6 \mathrm{MW}$ & 6 to 9 MW & Over 9 MW & \\
\hline Population & 161,627 & 475,814 & 247,208 & 197,893 & - \\
\hline Number of lawsuits filed & 89 & 417 & 407 & 336 & - \\
\hline Costs of lawsuits & $285,427.58$ & $1,280,606.35$ & $1,826,535.36$ & $1,472,447.36$ & - \\
\hline $\begin{array}{l}\text { Number of lawsuits per } 1,000 \\
\text { inhabitants }\end{array}$ & 0.55 & 0.88 & 1.65 & 1.70 & $0.001 * *$ \\
\hline $\begin{array}{l}\text { Average cost of lawsuits per } \\
\text { inhabitant }\end{array}$ & 1.77 & 2.69 & 7.39 & 7.44 & $0.0001 * *$ \\
\hline \multicolumn{6}{|c|}{ Origin of prescriptions by health care service } \\
\hline $\begin{array}{l}\text { Average from Public Health } \\
\text { Service }\end{array}$ & 3.58 & 3.92 & 5.17 & 3.30 & 0.5 \\
\hline $\begin{array}{l}\text { Average from Private Health } \\
\text { Service }\end{array}$ & 6.00 & 7.96 & 21.08 & 16.92 & $0.004 * *$ \\
\hline \multicolumn{6}{|l|}{ Availability of requested drugs } \\
\hline $\begin{array}{l}\text { Average number of standard } \\
\text { drugs in official lists per } 1,000 \\
\text { inhabitants }\end{array}$ & 0.95 & 1.68 & 3.48 & 3.08 & $0.0004 * *$ \\
\hline $\begin{array}{l}\text { Average number of nonstandard } \\
\text { drugs in official lists per } 1,000 \\
\text { inhabitants }\end{array}$ & 0.98 & 1.37 & 2.74 & 2.2 & $0.008^{* *}$ \\
\hline $\begin{array}{l}\text { Average number of } \\
\text { drugs representing } \\
\text { pharmacotherapeutic gaps per } \\
1,000 \text { inhabitants }\end{array}$ & 0.35 & 0.5 & 0.98 & 0.84 & 0.01 \\
\hline
\end{tabular}

\footnotetext{
* Kruskal-Wallis test. ** Variable statistically different.
} 
TABLE II - Pharmacological groups and their respective therapeutic indications of group A from the ABC Curve drugs, in decreasing order of financial importance in Type I and IV Regions - Goiânia, Goiás. Brazil

\begin{tabular}{|c|c|c|c|c|c|}
\hline \multicolumn{3}{|c|}{ Type I Regions } & \multicolumn{3}{|c|}{ Type IV Regions } \\
\hline $\begin{array}{l}\text { Pharmacological } \\
\text { groups }\end{array}$ & $\begin{array}{l}\text { Therapeutic } \\
\text { indications }\end{array}$ & Total (R\$) & $\begin{array}{l}\text { Pharmacological } \\
\text { groups }\end{array}$ & $\begin{array}{l}\text { Therapeutic } \\
\text { indications }\end{array}$ & Total (R\$) \\
\hline Antibacterials & Bacterial infections & $110,548.64$ & $\begin{array}{l}\text { Insulin and } \\
\text { analogues }\end{array}$ & $\begin{array}{l}\text { Type } 1 \text { Diabetes } \\
\text { mellitus }\end{array}$ & $670,917.56$ \\
\hline Antineoplastics & Neoplasia & $64,372.20$ & Antineoplastics & Neoplasia & $415,742.84$ \\
\hline Antidepressives & Depression & $30,743.18$ & $\begin{array}{l}\text { Glycogenic } \\
\text { hormones }\end{array}$ & Human reproduction & $75,629.52$ \\
\hline $\begin{array}{l}\text { Anti-thrombotic } \\
\text { agents }\end{array}$ & $\begin{array}{l}\text { Cardiovascular } \\
\text { disease }\end{array}$ & $21,371.44$ & Antidepressives & Depression & $72,941.90$ \\
\hline $\begin{array}{l}\text { Insulin and } \\
\text { analogues }\end{array}$ & $\begin{array}{l}\text { Type } 1 \text { Diabetes } \\
\text { Mellitus }\end{array}$ & $17,578.15$ & Bronchodilators & $\begin{array}{l}\text { Chronic obstructive } \\
\text { pulmonary disease }\end{array}$ & $56,302.00$ \\
\hline Antiepileptics & Epilepsy & $17,026.41$ & $\begin{array}{l}\text { Antithrombotic } \\
\text { agents }\end{array}$ & $\begin{array}{l}\text { Cardiovascular } \\
\text { disease }\end{array}$ & $51,923.31$ \\
\hline $\begin{array}{l}\text { Lipid modifiers } \\
\text { (HMG reductase } \\
\text { inhibitors) }\end{array}$ & Dyslipidemia & $11,273.52$ & Antihypertensives & Arterial hypertension & $44,948.55$ \\
\hline Anti-Retrovirals & Retroviral infections & $8,001.84$ & $\begin{array}{l}\text { Parathyroid hormon } \\
\text { analogues }\end{array}$ & eOsteoporosis & $30,047.94$ \\
\hline Bronchodilators & $\begin{array}{l}\text { Chronic obstructive } \\
\text { pulmonary disease }\end{array}$ & $7,716.25$ & Local anesthetics & Local anesthesia & $28,038.18$ \\
\hline Muscle relaxants & Multiple sclerosis & $7,656.17$ & Urologics & Erectile dysfunction & $19,453.17$ \\
\hline $\begin{array}{l}\text { Oral hypo- } \\
\text { glycemiants }\end{array}$ & $\begin{array}{l}\text { Type } 2 \text { Diabetes } \\
\text { Mellitus }\end{array}$ & $7,511.40$ & Antiepileptics & Epilepsy & $17,415.96$ \\
\hline $\begin{array}{l}\text { Antiglaucoma } \\
\text { preparations and } \\
\text { miotics }\end{array}$ & Glaucoma & $5,102.98$ & Antibacterials & Bacterial infections & $15,225.30$ \\
\hline
\end{tabular}

\section{DISCUSSION}

The study results showed that the average cost of lawsuits varied among the regional groups. The average cost of suits increased with higher average income, being four-fold greater in the highest income group compared with the lowest.

Some findings may help explain this behavior. One important fact is that the petitioners living in the wealthiest regions most frequently requested drugs that represent new technologies for the treatment of chronic diseases. By contrast, residents of regions with lower incomes requested treatments for acute diseases, such as bacterial infections which, although requiring high-cost drugs, require only short-term treatment. Some authors have called attention to the inequity caused by so-called "Health Judicialization" (Vierea, Zucchi, 2007; Terrazas, 2008). This study served to verify that individuals living in regions with different social characteristics in the same city, had different needs concerning the guarantee of access to pharmacological treatment as part of their right to health care. These differences between socially disparate regions may indicate inequality of access to drugs through this route. However, there are no satisfactory data to affirm that these differences reflect inequity, considering inequity as unfair, unnecessary and avoidable differences (Whitehead, 1992).

This ecological approach may be useful in planning actions and health policies, since it allows tendencies and profiles in urban spaces to be highlighted; however it should be used with caution and drawing conclusions at an individual level from these findings should be avoided.

Both standard and non-standard drugs were analyzed. SUS prescribers were expected to recommend drugs freely available within the public network, since they know the lists of standard drugs. However, it was 
observed that prescriptions of nonstandard drugs were also present in prescriptions for SUS patients.

Some drugs such as those for glaucoma, alcoholism and gastroesophageal reflux treatment, among others, represented assistance gaps and should have been included in at least one list of public distribution thereby enlarging and increasing the pharmaceutical assistance coverage.

However, the majority of requested drugs was standard or had free therapeutic alternatives available under the SUS where other authors had previously observed the same pattern (Messeder, Osorio-de-Castro, Luiza, 2005; Vieira, Zucchi, 2007; Borges, 2005).

The request for drugs for conditions, whose treatment is already provided free under the SUS, may be explained by three reasons. The first is that the petitioners from the private health system, the majority of cases in this study, may have demanded drugs through the justice system because they were unaware of the availability of the drugs in the public system, where these users and their respective attending physicians or medical practice is out of step with the clinical protocols and the programmatic actions defined by SUS.

The second reason may be that, even though these drugs are present in official lists of drugs for free distribution, the petitioners may have faced difficulties accessing them. This refers to access in its broader sense, i.e., it is not only a question of the medication being available but it must also being accessible at the opportune moment and when the patient (user) is made to believe and feel welcome (Penchansky, Thomas, 1981).

The third reason involves new technologies that have not been incorporated to the public health system as an alternative to those already existing. Vieira and Zucchi (2007) identified qualitative deficiencies in treatments offered by the SUS for some diseases, indicating a need for review of the existing policies with possible inclusion of new technologies. However, this situation must be evaluated cautiously, since the existence of a new technology does not necessarily imply that it is better than those currently available (Rascati, 2010). The SUS must be critical and responsible when assimilating technologies.

Recently, the Pharmacy and Therapeutics Committee of the city has reviewed its REMUME (Goiânia, 2010) and incorporated a variety of drugs which were the subject of frequent judicial requests, amongst them insulin analogues and eye drops for glaucoma, indicating the influence that judicial demands have on the policy of access to drugs. The incorporation of these new drugs into the REMUME may indicate a concern by public powers in meeting the demands of SUS users. However, we observed variations in the lawsuit profiles in terms of needs among the different social segments. Consequently the medication access policies should be sensitive to these disparities. One of these variations is the request for insulin analogues, which was a major request among the wealthier segments of population, who in turn are not frequent SUS users.

Akin to diabetes, the main diseases reported in the suits were of a chronic nature and included metabolism, cardiovascular, central nervous system and gastric disorders as reported in previous studies (Vieira, Zucchi, 2007; Silva, Terrazas, 2009; Appio, 2007; Freire, 2003) explaining the cumulative nature of suits involving medication provision and consequent elevated expenditure with this component.

The allocation of a significant part of the invested resources in citizens' health with an assistance-only component may jeopardize the sustainability of the health care pattern developed. This is because, according to Ferraz (2008), when resources are lower than the necessary expenditure to cater for needs, two different outcomes can be expected as a consequence of this opportunity cost: a) assistance for all will be rendered unviable, i.e., it will be necessary to reduce the number of beneficiaries; or b) adjustment and compatibility between resources and expenditure will result in reduced quality of healthcare assistance. Given that since 1988 the exclusion of users is an unconstitutional act, the more probable and plausible alternative is a reduction in the quality of the assistance offered.

The imbalance between the constitutional proposal of universalization, the integrality of assistance and its financing, causes instability in the national health care system (Dain, 2007). The costing of drugs requested through lawsuits is a challenge to the SUS, and its sustainability is at risk while growth is higher than the resources available for health care.

A notable finding in this study was the participation of the Public Ministry (State Public Prosecutors) (PM) as the agent of the court actions in the majority of cases, unlike previous studies. Vieira and Zucchi (2007), Marques and Dallari (2007) in São Paulo, Pereira et al. (2004) in Santa Catarina found private attorneys to be the main agents. On the other hand, according to the studies by Messeder et al. (2005) and Romero (2008), public and/ or non-profit agents, such as Public Defenders, Model Offices and MP (State Public Prosecutors) were the predominant agents. However, they all found little or no MP participation in cases.

A high participation of the Public Ministry found in this study may call into question its legitimacy to file lawsuits to defend the interests of single citizens, deviating from its constitutional remit. However, the Brazilian 
Supreme Federal Court (STF) does not perceive court actions requesting means of health recuperation in this light. According to the courts, health is an inalienable right and in such cases, Article 127 of the Federal Constitution holds the Public Ministry responsible for acting in the defense of these individuals (Brasil, 2009). Moreover, in principle it is the role of the Public Defender Offices to defend poor SUS users who cannot afford to hire a lawyer to represent them in court, but for places where this office does not exist, the Public Ministry becomes an alternative for these citizens. This is the case of the city studied, and helps explain the extensive participation of the Public Ministry in the health care lawsuits.

Despite the Public Ministry being a legitimate representative of needy individuals, the study observed that the majority of lawsuits had originated from urban regions associated with the highest incomes. The number of actions in the two segments with the highest income was 1.5-fold higher than in the two segments with the lowest income. Vieira and Zucchi (2007) and Chieffi and Barata (2009) also observed a higher number of lawsuits originating from regions with better social conditions.

This profile may be associated with the patients' relationship network facilitating access to the necessary information to grant their constitutional rights. This is relevant because patients are generally unaware of their rights until somebody informs/guides them (Leite, Mafra, 2010) and the physician has an important role in this relationship network, acting as the main informer (Leite, Mafra, 2010; Terrazas, 2008).

Other differences were observed among regions with differing average salaries. One of these differences was expected, namely, the origin of prescriptions in the private health system was more frequent in segments with higher income, i.e., it was expected that people from wealthier regions did not use the Unified Health System (SUS), opting for supplementary health services, as observed in other studies (Terrazas, 2008; Vieira, Zucchi, 2007). Looking to the public sector to overcome lack of access and integrality of care in a public/private mix are measures people resort to in their health care quotidian influenced by health plan coverage (Leite, Mafra, 2010).

The health judicialization phenomenon has been extensively studied and described, along with its social, ethical, economic, administrative and sanitary consequences. However, this problem interferes in SUS management in the three government spheres, with greatest impact at municipal level, since cities have tighter budgets.

Some related factors include the influence of the pharmaceutical industry, high cost of treatment, unavailability of drugs under the public health care system, among others (Provin, Delduque, Amaral, 2012) although only a few of these factors have a well-established causeeffect relationship.

Nevertheless, some measures have been adopted in a bid to tackle the problem, such as taking the administrative route (non-judicial) to request drugs as an alternative to the judicial route and the adoption of Technical Chambers. However, both these solutions come into play only after the demand has been filed, while none propose to deal with the root problem, i.e., act in a preventive and efficient manner aiming to make demands that are out of flow an exception.

Among the list of causes related to the judicial and extrajudicial demands, several are outside the realm of SUS management, however, those originating from within the health system should be elucidated and their relationship with the problems resulting in the demands should be determined and addressed via alternative routes. Subsequently, these problems should be analyzed in-depth in order to tackle the root problem.

As the problem in hand is multifactorial, there may well be no definitive solution to remedy it, but these demands should be kept at levels compatible with efficient management of public resources while upholding the universality and integrality principle.

\section{CONCLUSION}

The judicial demand profile in intracity regions with different incomes exhibited distinct characteristics, and may represent diverse needs in terms of guaranteeing the right to health care, particularly concerning the provision of drugs. Population segments with higher incomes filed lawsuits more frequently to assure their access to drugs and also requested more expensive treatments.

\section{REFERENCES}

APPIO, E. Controle Judicial das Políticas Públicas no Brasil. Porto Alegre: Juruá, 2007. 288p.

BONFIM, R.L.D. Agenda única de saúde: a busca do acesso universal e a garantia do direito à saúde. Rio de Janeiro, 2008. 164 f. [Thesis of PhD degree. Institute of Social Medicine. Federal University of Rio de Janeiro].

BORGES, D.C.L. Uma análise das ações judiciais para o fornecimento de medicamentos no âmbito do SUS: o caso do Estado do Rio de Janeiro no ano de 2005. Rio de Janeiro, 2007. 117 f. [Dissertion of Master degree. Oswaldo Cruz Foundation / Public Health School of Sérgio Arouca]. 
BORGES, D.C.L; UGÁ, M.A.D. Conflicts and impasses in the judicialization of the supply of medicines: circuit court rulings on claims brought against the State of Rio de Janeiro, Brazil, in 2005. Cad. Saúde Pública, v.26, n.1, p.59-69, 2010.

BRASIL. Constituição (1988). Constituição da República Federativa do Brasil. Brasília, DF: Senado, 1988.

BRASIL. Lei 8.080 de 19 de setembro de 1990. Dispõe sobre as condições para a promoção, proteção e recuperação da saúde, a organização e o funcionamento dos serviços correspondentes e dá outras providências. Brasília, DF. Available at: <http://www.planalto.gov.br/ccivil/LEIS/ 18080.htm>. Accessed on: 03 Feb. 2010.

BRASIL. Lei 9.787 de 10 de fevereiro de 1999. Altera a Lei $n^{\circ} 6.360$, de 23 de setembro de 1976, que dispõe sobre a vigilância sanitária estabelece o medicamento genérico, dispõe sobre a utilização de nomes genéricos em produtos farmacêuticos e dá outras providências. Poder Executivo: Diário Oficial da União, 1999. Available at: <http://www. anvisa.gov.br/hotsite/genericos/legis/leis/9787.htm>. Accessed on: 03 Feb. 2010.

BRASIL. Ministério do Planejamento, Orçamento e Gestão. Instituto Brasileiro de Geografia e Estatística - IBGE. Censo Demográfico 2000. Agregado por setor censitário dos resultados do universo. v.10: Região Centro Oeste. 2.ed. Rio de Janeiro: IBGE; 2003. CD-ROM.

BRASIL. Recurso extraordinário 407.902-0 Rio Grande do Sul, da $1^{a}$ Turma do Tribunal de Justiça do Estado do Rio Grande do Sul, Distrito Federal: Supremo Tribunal Federal, 2009. Available at: http://redir.stf.jus.br/paginador/ paginador.jsp?docTP $=\mathrm{AC} \&$ docID $=601644$. Accessed on: 17 Dec. 2010.

CHIEFFI, A.L; BARATA, R.B. "Judicialization" of public health policy for distribution of medicines. Cad. Saúde Pública, v.25, n.8, p.1839-1849, 2009.

CONILL, E.M; PIRES, D; SISSON, M.C; OLIVEIRA, M.C; BOING, A.F; FERTONANI, H.P. The public-private mix and health service utilization: a study of the therapeutic itineraries of Brazilian supplementary care beneficiaries. Ciênc. Saúde Colet., v.13, n.5, p. 1501-1510, 2008.

DAIN, S. Os vários mundos do financiamento da saúde no Brasil: uma tentativa de integração. Ciênc. Saúde Colet., v.2, suppl.1, p.1851-1864, 2007.
FERRAZ, M.B. Dilemas e escolhas do sistema de saúde: economia da saúde ou saúde da economia? Rio de Janeiro: Medbook, 2008. 192p.

FREIRE, A.M.P. Constitucionalismo garantista y democracia. Revista Crítica Jurídica, n. 22, p. 31-65, (Jul-Dez), 2003. Available at: http://www.juridicas.unam.mx/publica/librev/ rev/critica/cont/22/pr/pr5.pdf. Accessed on: 22 Oct. 2010.

GOIÂNIA. Relação municipal de medicamentos essenciais. 2010. Available at: http://prefeituragoiania.stiloweb.com. br/site/download/saude/REMUME. (PDF). Accessed on: 10 Jan. 2011.

LEITE, S.N; MAFRA, A.C. What right? Trajectories and perceptions of users in relation to the process of access to medication by legal writ in Santa Catarina State. Ciênc. Saúde Colet., v.15, suppl.1, p. 1665-1672, 2010.

LEITE, S.N; PEREIRA, S.M.P; SILVA, P.; NASCIMENTO JR, J.M.; CORDEIRO, B.C.; VEBER, A.P. Legal actions and administrative demands related to the guarantee of the right to drugs access in the city of Florianópolis-SC. Rev. Direito Sanitário, v.10, n.2, p.13-28, 2009.

MARQUES, S.B; DALLARI, S.G. Safeguarding of the social right to pharmaceutical assistance in the state of São Paulo, Brazil. Rev. Saúde Pública, v.41, n.1, p. 101-107, 2007.

MESSEDER, A.M.; OSORIO-DE-CASTRO, C.G.S.; LUIZA, V.L. Can court injunctions guarantee access to medicines in the public sector? The experience in the State of Rio de Janeiro, Brazil. Cad. Saúde Pública, v.21, n.2, p.525-534, 2005.

PENCHANSKY, D.B.A.; THOMAS, J.W. The concept of access - definition and relationship to consumer satisfaction. Med. Care, v.19, n.2 p.127-140, 1981.

PEREIRA, J.R.; SANTOS, R.I.; NASCIMENTO JR, J.M.; SCHENKEL, E.P. Situation of lawsuits concerning the access to medical products brought against the Health Department of Santa Catarina State, Brazil, during the years 2003 and 2004. Ciênc. Saúde Colet., v.15, supl.3, p.3551-3560, 2010.

PROVIN, M.P.; DELDUQUE, M.C.; AMARAL, R.G. Aspectos jurídicos e sanitários condicionantes para o uso da via judicial no acesso aos medicamentos no Brasil. Rev. Salud Pública, v.14, n.2, p.340-349, 2012. 
RASCATI, K.L. Introdução à farmacoeconomia. Porto Alegre: Artmed, 2010. 280 p.

ROSA, M.B; GOMES, M.J.V.M.; REIS, A.M.M. Abastecimento e gerenciamento de materiais. In: GOMES, M.J.V.M.; REIS, A.M.M. Ciências farmacêuticas: uma abordagem em farmácia hospitalar. Rio de Janeiro: Atheneu Editora, 2001.

ROMERO, L.C. Judicialização das políticas de assistência farmacêutica: o caso do Distrito Federal. Texto para discussão 41. Brasília, May 2008. Available at: <http:// www2.senado.gov.br/bdsf/item/id/96829>. Accessed on: 17 Feb. 2009.

SCHWARTZ, T.D.; FERREIRA, J.T.B.; MACIEL, E.L.N.; LIMA, R.C.D.L. Estratégia saúde da família: avaliando o acesso ao SUS a partir da percepção dos usuários da Unidade de Saúde de Resistência, na região de São Pedro, no município de Vitória (ES). Ciênc. Saúde Colet., v.15, n.4, p.2145-2154, 2010.

SILVA, N.N.; PEDROSO, G.C.; PUCCINI, R.F.; FURLANI, W.J. Social inequalities and health services use: evidences from a stratified household survey. Rev. Saúde Públ., v.34, n.1, p.44-49, 2000.

SILVA, V.A.; TERRAZAS, F.V. Claiming the right to health in brazilan courts: the exclusion of the already excluded. SSRN-Social Science Research Network, 2009. Available at: $<$ http//:ssrn.com/abstract $=1133620>$. Accessed on: 30 July 2009.

TERRAZAS, F.V. O Poder Judiciário como voz institucional dos pobres: o caso das demandas judiciais por medicamentos. São Paulo, 2008. 56p. [Dissertion of master degree. Faculty of Law. State University of São Paulo].
TRAVASSOS, C. Eqüidade e o Sistema Único de Saúde: uma contribuição para debate. Cad. Saúde Pública, v.13, n.2, 1997. Available at: <http://www.scielo.br/ scielo.php?script $=$ sci_arttext\&pid=S0102-311X1997000 200024\&lng=en\&nrm=iso $>$. Accessed on: 28 Oct. 2010.

TRAVASSOS, C.; OLIVEIRA, E.X.G.; VIACAVA, F. Geographic and social inequalities in the access to health services in Brazil: 1998 and 2003. Ciênc. Saúde Colet., v.1, n.4, p.975-986, 2006.

VIEIRA, F.S.; ZUCCHI, P. Distortions to national drug policy caused by lawsuits in Brazil. Rev. Saúde Públ., v.41, n.2, p.214-222, 2007.

VIEIRA, F.S.; ZUCCHI, P. Patient lawsuits and treatment provision on the Brazilian National Health Service. Rev. Assoc. Med. Bras., v.56, n.6, p.672-683, 2010.

WHITEHEAD, $\mathrm{M}$. The concepts and principles of equity and health. Int. J. Health Serv., v.22, n.3, p.429-445, 1992.

WORLD HEALTH ORGANIZATION. Collaborating Centre for Drug Statistics Methodology. WHO International Working Group for Drugs Statistics Methodology. Sistem ATC/DDD. Geneva: WHO, 2010. Available at: http://www. whocc.no/atc_ddd_index/.Accessed on: 18 May 2010.

Received for publication on $22^{\text {nd }}$ May 2012 Accepted for publication on $04^{\text {th }}$ May 2013 